Policy Research Working Paper 3069

\title{
International Migration, Remittances, and the Brain Drain
}

\section{A Study of 24 Labor-Exporting Countries}

Richard H. Adams, Jr.

The World Bank

Poverty Reduction and Economic Management Network

Poverty Reduction Group

June 2003 
Policy Research Working Paper 3069

\begin{abstract}
While the level of international migration and remittances continues to grow, data on international migration remains unreliable. At the international level, there is no consistent set of statistics on the number or skill characteristics of international migrants. At the national level, most labor-exporting countries do not collect data on their migrants.

Adams tries to overcome these problems by constructing a new data set of 24 large, labor-exporting countries and using estimates of migration and educational attainment based on United States and OECD records. He uses these new data to address the key policy question: How pervasive is the brain drain from labor-exporting countries?

Three basic findings emerge:

- With respect to legal migration, internarional migration involves the movement of the educated. The vast majority of migrants to both the United States and
\end{abstract}

the OECD have a secondary (high school) education or higher.

- While migrants are well-educated, international migration does not tend to take a very high proportion of the best educated. For 22 of the 33 countries in which educational attainment data can be estimated, less than 10 percent of the best educated (tertiary-educated) population of labor-exporting countries has migrated.

- For a handful of labor-exporting countries, international migration does cause brain drain. For example, for the five Latin American countries (Dominican Republic, El Salvador, Guatemala, Jamaica and Mexico) located closest to the United States, migration takes a large share of the best educated. This finding suggests that more work needs to be done on the relationship between brain drain, geographical proximity to labor-receiving countries, and the size of the (educated) population of labor-exporting countries.

This paper-a product of the Poverty Reduction Group, Poverty Reduction and Economic Management Network-is part of a larger effort in the network to better understand how international migration and remittances affect developing countries. Copies of the paper are available free from the World Bank, $1818 \mathrm{H}$ Street NW, Washington, DC 20433. Please contact Nelly Obias, room MC4-834, telephone 202-473-1986, fax 202-522-3283, email address nobias@worldbank.org. Policy Research Working Papers are also posted on the Web at http://econ.worldbank.org. The author may be contacted at radams@worldbank.org. June 2003.(29 pages)

The Policy Research Working Paper Series disseminates the findings of work in progress to encourage the exchange of ideas about development issues. An objective of the series is to get the findings out quickly, even if the presentations are less than fully polished. The papers carry the names of the authors and should be cited accordingly. The findings, interpretations, and conclusions expressed in this paper are entirely those of the authors. They do not necessarily represent the view of the World Bank, its Executive Directors, or the countries they represent. 
International Migration, Remittances and the Brain Drain:

A Study of 24 Labor-Exporting Countries*

Richard H. Adams, Jr.

PRMPR

World Bank

1818 H Street, $N W$

Washington, DC 20433

Phone: 202-473-9037

E-Mail: radams@worldbank.org

*I would like to thank Maureen Lewis and Zafiris Tzannatos for useful comments on an earlier draft. 

Within the last decade an increasing amount of attention has focused on the relationship between international migration, brain drain, and economic growth. Since education has often been cited as a major determinant of long-term economic growth, conventional wisdom has typically argued that the international migration of people endowed with a high level of human capital - the so-called "brain drain" - is detrimental for the country of emigration. ${ }^{\prime}$ According to this argument, the large-scale departure of highly-educated workers from developing countries tends to depress income levels and long-run economic growth rates in the developing world.

This conventional view, however, has recently been challenged by the following argument. In a developing economy with a limited growth potential, the return to human capital is likely to be low. This in turn would lead to limited incentive to acquire education, which is seen as the engine of economic growth. However, since the world at large values education, allowing migration of the "best and brightest" from a developing country may actually increase the incentive to acquire education. Since only a small faction of educated people in a specific country would migrate, this would encourage the average level of education of the remaining population to rise.

Deciding which of these arguments is most accurate is difficult, given the paucity of available information on the level and characteristics of international migration. For example, at the international level, there is no consistent or reliable system of data on either the number or skill characteristics of international migrants. Moreover, at the

\footnotetext{
'By "brain drain" this study does not mean the migration of engineers, physicians or other very highly skilled professions, but simply, the migration of more than 10 percent of the tertiary-educated population of a particular labor-exporting country.
} 
national level, labor-exporting countries do not typically keep track either of the number or the skill characteristics of migrants. And while some labor-receiving countries do keep track these issues, they often use different definitions of immigration. As a result of these data problems, a host of key policy questions remain unanswered. Exactly how pervasive is the brain drain? Which countries or regions of the developing world are most affected? Does international migration deprive labor-exporting countries of a sizeable fraction of their "best and brightest," or are their numbers too small to worry about?

This paper proposes to answer these, and similar questions, by developing a new data set composed of 24 large, labor-exporting countries. ${ }^{2}$ This data set includes all those developing countries which received more than $\$ 500$ million dollars in official worker remittances in the year $2000 .^{3}$ To ensure representativeness, the data set includes countries drawn from each major region of the developing world: Latin America and the Caribbean, Middle East and North Africa, Europe and Central Asia, East Asia, South Asia and Sub-Saharan Africa.

The paper uses this new data set to do the following three tasks. First, in order to provide some perspective on the importance of international migration, the paper shows how the level of worker remittances received by these 24 labor-exporting countries has increased over time. Second, using data collected by the two main labor-receiving

\footnotetext{
${ }^{2}$ The 24 study countries include: Brazil, Colombia, Dominican Republic, El Salvador, Guatemala, Jamaica, Mexico, Peru (Latin America and Caribbean); Egypt, Morocco, Tunisia (Middle East and North Africa); Albania, Armenia, Croatia, Turkey (Europe and Central Asia); China, PR, Indonesia, Philippines (East Asia); Bangladesh, India, Pakistan, Sri Lanka (South Asia); and Nigeria and the Sudan (Sub-Saharan Africa).

${ }^{3}$ The source of all data on official worker remittances in this study is: International Monetary Fund, Balance of Payments Statistics Yearbook.
} 
regions in the world (United States and OECD), ${ }^{4}$ the paper provides estimates of the total level of migration from each of the 24 study countries. Finally, the paper uses data from the 2000 U.S. Population Census and estimates from the 2001 OECD Continuous Reporting System on Migration to show the stock of migrants by educational level (primary, secondary and tertiary) ${ }^{5}$ in the two main labor-receiving regions. These data also show the fraction of the population in each educational category in each laborexporting country that has migrated to the United States or the OECD. ${ }^{6}$ The latter estimates, which are quite rough and in need of further refinement, provide some sense of the magnitude of the brain drain from each of the 24 labor-exporting countries.

Results from the study show that international migrants are well-educated: 67 percent of all immigrants to the United States and 88 percent of those to the OECD have a secondary (high school) education or higher. While these figures do not include the large numbers of illegal (and presumably less educated) international migrants, it does appear that uneducated individuals have limited access to legal international migration. International migrants also tend to be much better educated that the rest of the population of their country of origin. However, in terms of actual brain drain on their country of origin, international migration does not seem to take a very high proportion of the best educated (tertiary). For example, with respect to migration to the United States. for 14 of

\footnotetext{
${ }^{4}$ Unfortunately, no data are available on the level of migration to the third most important labor-receiving region in the world: the Arab Gulf. The OECD includes 30 member countries : Australia, Austria, Belgium, Canada, Czech Republic, Denmark, Finland, France, Germany, Greece, Hungary, Iceland, Ireland, Italy, Japan, Korea, Luxembourg, Mexico, Netherlands, New Zealand, Norway, Poland, Portugal, Slovak Republic, Spain, Sweden, Switzerland, Turkey, United Kingdom, and United States.

${ }^{5}$ Primary education is defined as 0 to 8 years of schooling; secondary is 9 to 12 years; and tertiary is 13 years and above.

${ }^{6}$ For the OECD, estimates of the fraction of population in each educational category from each study country are taken from Carrington and Detragiache (1998).
} 
the 20 countries for which data exist, international migration takes less than 10 percent of the population with a tertiary education. Migration to the OECD results in a slightly higher degree of brain drain, but even here international migration takes more than 10 percent of the tertiary-educated population from only 5 of 13 labor-exporting countries.

The balance of the paper is organized as follows. To provide perspective on the growing importance of international migration, Section II presents data on changes in the level of worker remittances received in the 24 countries over the last twenty years. Section III explains the methodology used for estimating the level of migration to the United States and the OECD. Section IV applies this methodology to estimate the extent of brain drain to the United States by analyzing migration rates and the educational composition of U.S. migrants. Estimates of the level of brain drain to the OECD are presented using similar methods in Section V. Section VI concludes.

\section{Official Remittances from International Migration}

To gain a proper perspective on the importance of international migration, it is best to begin with the most visible product of international migration: remittances received. Not only are remittances critical to the foreign exchange position of many labor-exporting countries, but they are also vital to the consumption and investment behavior of migrant households themselves. Perhaps because of their importance to both labor-exporting countries and households, remittances tend to be the best measured and recorded aspect of the migration experience. For instance, the International Monetary Fund (IMF) keeps annual records of the amount of worker remittances received by each 
labor-exporting country. ${ }^{7}$ No other organization - national or international - collects and publishes annual records on any other part of the international migration process.

It should, however, be noted that the IMF only reports data on official worker remittance flows, that is, remittance monies which are transmitted through official banking channels. Since a large (and unknown) proportion of remittance monies is transmitted through informal, unofficial channels, the level of remittances recorded by the IMF underestimates the actual flow of remittance monies returning to labor-exporting countries. For instance, a recent IMF study (El-Qorchi, Maimbo and Wilson, 2002) estimated that informal transfers of remittance monies could amount to $\$ 10$ billion per annum. $^{8}$

Despite these problems, Table 1 shows the level of official worker remittances received by each of the 24 study countries over the twenty-year period, 1981 to 2000 . Total official remittances - measured in real terms - for the 24 labor-exporting countries now amount to over $\$ 36$ billion per annum. Among the study countries, the three largest recipients of official worker remittances in 2000 are: India ( $\$ 7,994$ billion), Mexico ( $\$ 5,816$ billion) and Turkey ( $\$ 4,035$ billion). Mexico is also one of the countries recording the largest percentage rate of increase in remittances over the twenty-year period.

It is interesting to note that that each of the three largest remittance-receivers is sending migrants to a different labor-receiving region. Although data are scanty, India is

\footnotetext{
${ }^{7}$ The IMF records annual flows in international remittances in its publication, Balance of Payments Statistics Yearbook.

${ }^{8}$ Focusing on the hawala system of informal transfer, this IMF study of 15 developing countries (2002: 64) estimated that about $\$ 35$ billion per annum of remittance monies was transmitted through informal channels in the early 1980 s, falling to $\$ 10$ billion per annum in more recent years. The decline in the level of informal transfers was attributed to the disappearance of the black market exchange premiums in many developing countries during the 1990 s.
} 
probably sending most of its migrants to the OECD and the Arab Gulf. Because of its proximity to the United States, Mexico is sending most of its migrants to its northern neighbor. Turkey, the third largest remittance-receiver, is sending most of its migrants to the OECD (especially Germany).

Table 2 provides another way of looking at the flow of official remittances. Here the data on worker remittances for the 24 countries are disaggregated by region of the world. Because of the importance of the United States as a labor-receiving region, Latin America and the Caribbean is the largest recipient of official remittances. This region of the world also recorded the highest percentage rate of increase in official worker remittances over the last twenty years.

For the 24 study countries as a whole, Table 2 reveals that official worker remittances have increased at a strong 3.86 percent per year in real terms. To put this figure into perspective, Table 3 compares the annual rate of growth in official remittances for the 24 study countries with that of gross domestic product (GDP) for various regions of the developing world. For the twenty-year period, official remittances grew at a faster annual rate than did GDP in 119 low and lower middle-income developing countries (3.86 versus 1.61 percent per year). In two of the six regions of the developing world (Latin America and the Caribbean, Sub-Saharan Africa), official remittances also grew at a faster annual rate than did GDP. 


\section{Methodology for Estimating Levels of Migration}

Since few, if any, of the major labor-exporting countries keep accurate records on either the number or the educational characteristics of migrants, it is necessary to estimate these variables by using data collected by the main labor-receiving countries. For the purposes of this paper, the main labor-receiving countries (regions) include two: United States and the OECD. The third large labor-receiving region - the Arab Gulf - does not publish any data on the number or characteristics of migrants, and thus will not be included in this study.

IIIa. Estimating Migration to the United States

Following the pioneering methodology of Carrington and Detragiache (1998), ${ }^{9}$ this study employs four steps to estimate migration rates and the educational attainment of migrants to the United States.

The first step is to use data from the newly released files of the 2000 U.S. Population Census on the "place of birth for the foreign-born population." Fortunately, these data are disaggregated by country of birth for about 50 specific countries. However, it is not clear whether all of the "foreign-born" population are, in fact migrants. For example, a person born in Mexico and brought to the United States as an infant would probably not consider himself as a migrant. Moreover, it is also not clear how many of those who enter the United States illegally are, in fact, included in the "foreignborn" population figures. As some observers have suggested, the U.S. Census data may be grossly undercounting the actual migrant population that is living - legally or illegally

\footnotetext{
${ }^{9}$ While the Carrington and Detragiache (1998) study is based upon data from the 1990 U.S. Population Census, this study uses newly released data from the 2000 U.S. Census.
} 
- in the United States. ${ }^{10}$ Since illegal migrants are likely to be less educated than legal migrants, this may in turn lead to an overestimate of the average level of migrant education. This source of bias, however, should not seriously distort our estimates of the migration rate of individuals with tertiary education, since those with higher levels of education are more likely to be in the United States on a legal basis.

The second step is to estimate from the 2000 U.S. Census data the number of "foreign born" from each country who are 25 years of age or older. This is necessary to maximize the comparability of the immigrant population from each country with the Barro and Lee (2000) data set, which measures the educational attainment of the population over the age of 25 in each country.

The third step is to calculate for each population from each labor-exporting country the number of migrants in three specific educational categories: primary or less (0-8 years of schooling), secondary (9-12 years of schooling) and tertiary (13 or more years of schooling). For the United States, this is done by using data from a special tabulation from the 2000 U.S. Census done by the U.S. Census Bureau. This special tabulation shows by county of origin the educational attainment level of the foreign born population living in the United States in the year 2000.

The final step is to use the Barro and Lee educational attainment data set to compute migration rates for each labor-exporting country for the same three educational categories mentioned above. These calculations enable us to show what fraction of each country's educational group has migrated to the United States.

\footnotetext{
${ }^{10}$ In 1992 the stock of illegal immigrants in the United States was estimated at 3.4 million, or about 16 percent of the stock of the "foreign-born" population (Borjas, 1995).
} 
Since this study relies heavily upon the educational attainment data contained in Barro and Lee (2000), it is useful to describe this data set in some detail. Barro and Lee base their estimates of the educational attainment of the population in various countries on either the most recent census data or on historical schooling enrollment figures. In cases where enrollment figures are used, estimates of the current stock of education are constructed using a perpetual inventory method. Of course, various factors (including migration) may distort estimates based on historical enrollment patterns. Nevertheless, the Barro and Lee data set represents the best available set of estimates of educational attainment for a broad cross-section of developing countries.

IIIb. Estimating Migration to the OECD

For OECD countries, data on migration flows by country are collected and published in Trends in International Migration: Annual Report (2001). Unfortunately, these data are not as comprehensive as the U.S. Census data, and they differ from the United States data in at least three key ways.

First, and most importantly, the data for OECD countries do not report the educational attainment of migrants. For example, no data are available on the educational distribution of Turkish migrants to Germany. For the lack of alternative, we will assume that the educational distribution of migrants from each labor-exporting country to the OECD is the same as that for the United States. ${ }^{11}$ In other words, if 40 percent of Turkish migrants to the United States have a tertiary education, we will assume that the same percentage of Turkish migrants to the OECD have this level of education. This procedure is most likely to be accurate for those labor-exporting

\footnotetext{
${ }^{11}$ This is the same strategy used by Carrington and Detragiache (1998) in their study of brain drain.
} 
countries which send similar numbers of migrants to both the United States and the OECD. However, for some labor-exporting countries - like Tunisia or Turkey - which send much larger numbers of migrants to the OECD than to the United States, this procedure is likely to be quite problematic. For instance, our procedure will impute to the German Turks the same high level of education as is found in their United States counterparts. This may, in turn, lead to a gross overestimate of the brain drain from a country like Turkey.

The second problem with the OECD data lies in its different way of classifying immigrants. Since United States-born children of immigrants have US citizenship, the United States defines an immigrant as a person who was born abroad to non-US citizens. Most OECD countries, however, follow an ethnicity-based definition of immigration status. This method classifies a person on the basis of the ethnicity of the parent, rather than on place of birth. Thus, a child of Turkish parents born in Germany is typically classified as an immigrant. This different way of classifying immigrants has the net effect of increasing the stock of immigrants in any particular OECD country, and perhaps biasing our estimates of the educational status of "migrants" who were actually born, raised and educated in that OECD country.

The third difference between the OECD and the United States data has to do with the number of labor-exporting countries recorded. As noted above, the 2000 U.S. Census data can be used to count the number of migrants from about 50 different labor-exporting countries. By contrast, for each OECD country, OECD data only record the number of migrants from approximately the top fifteen-labor exporting countries. On the one hand, this might not be a significant problem for large labor-exporting countries, like Turkey. 
However, for smaller labor-exporting countries, like Brazil or Sri Lanka, the actual number of migrants to any particular OECD country might not be recorded. This makes it difficult to accurately compare and contrast migration rates between different laborexporting countries.

IV. Brain Drain to the United States: Migration Rates and Educational Levels

This section presents estimates of immigrants in the United States by educational attainment, both in absolute number and as a fraction of the individuals in the laborexporting country with the same level of educational attainment. As explained in the previous section, following the reporting conventions of the U.S. Census Bureau, these figures consider as immigrants all "foreign-born" individuals residing in the United States. Thus, these figures may well include substantial numbers of people who are not usually regarded as either migrants or as part of the brain drain, such as individuals who migrated to the United States as children and have few ties with their original country of birth.

Table 4 presents immigration data to the United States for all 24 study countries. It is striking to note that one single country - Mexico - dominates migration to the United States. In our sample about 50 percent of all immigrants in the United States come from Mexico! ${ }^{12}$ The second largest source of immigrants is the China, PR, which supplies less than 10 percent of total migrants.

Table 4 shows the key role that education plays in migration. In the sample as a whole, about 67 percent of all immigrants have a secondary education or higher. This

\footnotetext{
${ }^{12}$ According to the 2000 U.S. Population Census, of the total foreign-born population in the United States $(31,107,000)$, Mexico accounts for 29.5 percent $(9,177,000)$
} 
figure is even higher if the very large number of poorly educated immigrants from one single country (Mexico) are excluded. Excluding Mexico from the sample, 83 percent of all migrants to the United States have a secondary education or higher.

As the case of Mexico suggests, the educational attainment level of migrants varies considerably from country to country. Focusing on those immigrants with the highest level of education (tertiary), the share of immigrants to the United States with a tertiary education varies from a low of 14 percent (Mexico) to a high of 80 percent (India). In general, there is a strong tendency for the level of educational attainment to vary inversely with distance from the United States. Latin American and Caribbean countries generally produce a lower share of migrants with a tertiary education, while those countries which are more distant (particularly in South Asia) produce the highest share of tertiary-educated migrants. ${ }^{13}$ This phenomenon may reflect the impact of migration costs (both financial and time). That is, prospective migrants with low levels of education in countries which are close to the United States are better able to afford the costs of legal (and illegal) migration than similar prospective migrants in more distant countries.

Table 5 presents estimated migration rates by educational category for each laborexporting country. Focusing on the highest (tertiary) level of education, the results suggest that - for most countries -- migration to the United States is not causing much brain drain. For 14 of the 20 countries for which data exist, less than 10 percent of those with a tertiary education have migrated to the United States. This result even holds for China, PR, which is the third-largest source of immigrants to the United States (see Table

\footnotetext{
${ }^{13}$ According to Table 4, while the share of tertiary-educated migrants from South Asia is 76.5 percent, the share of such migrants from Latin America and the Caribbean is only 19.8 percent.
} 
4). In China, PR, only 2 percent of those with a tertiary education have migrated to the United States.

However, for a handful of countries, Table 5 reveals that migration to the United States does cause brain drain. For the five Latin American countries (Dominican Republic, El Salvador, Guatemala, Jamaica and Mexico) located closest to the United States, migration takes a large share of the best educated. While 16 percent of those with a tertiary education in Mexico migrate to the United States, over 360 percent of those with this level of education in Jamaica migrate. The very high migration rate of the best educated from Jamaica means that the number of migrants with a tertiary education from this country actually exceeds the number of local residents with this level of education. In other words, the estimated figure for tertiary-educated migrants from Jamaica must somehow overstate the true size of the brain drain from that country.

The second theme in Table 5 is that low-skilled migration to the United States is not very important for most labor-exporting countries. There are only two countries (E)Salvador and Mexico) for which the migration rate for those with a primary school or less education is greater than 10 percent. The highest figure for primary school migrants is that of El Salvador (12.4 percent), followed by Mexico (10.8 percent). While the migration data in Table 5 do not include the sizeable (and unknown) number of illegal migrants in the United States, who probably have much lower levels of education, the results for legal migration seem clear. Legal migration to the United States involves the movement of better educated people, people who are probably more educated than those who remain at home. 
The final finding in Table 5 is that total migration rates to the United States are not very high for most countries. Total migration rates exceed 10 percent for only four countries: Dominican Republic, El Salvador, Jamaica and Mexico. All four of these countries are in Latin America, and three of them have fairly small populations. ${ }^{14}$ It should come as no surprise that small, Latin American countries have high average rates of migration because this is a consequence of United States immigration policy. By setting annual limits on the numbers of migrants that can come from each labor-exporting country, regardless of size, United States policy in effect favors lightly-populated countries in the Western Hemisphere. A limit of 20,000 legal migrants per year per country is much more of a binding constraint for Pakistan than it is for Jamaica, and this is one reason why Jamaica has the highest total migration rate ( 33.3 percent) in the table.

\section{Brain Drain to the OECD: Migration Rates and Educational Levels}

Table 6 presents data for 13 of the 24 study countries for which immigration data to the OECD exist. As in the case of immigration to the United States, one country dominates: Turkey. In our sample about 40 percent of all immigrants to the OECD come from Turkey. The second largest source of immigrants in our sample is China, PR, which supplies about 15 percent of total migrants. Two North African countries -- Morocco and Tunisia -- combine together to produce about 15 percent of all migrants to the OECD.

Table 6 shows that education plays an even more important role in migration in the OECD than in the United States. While 67 percent of all immigrants to the United

\footnotetext{
${ }^{14}$ The Dominican Republic, El Salvador and Jamaica each have a total (2000) population of less than 10 million.
} 
States have a secondary education or higher, fully 88 percent of all immigrants to the OECD have this level of education. Moreover, of these secondary-educated immigrants to the OECD, over two-thirds -- 69 percent -- have a tertiary education.

However, it is important to emphasize that these estimates of the number of educated migrants probably overestimate the true extent of the brain drain to the OECD for two reasons. First, levels of educational attainment for migrants to the OECD must be estimated, rather than observed as in the United States, because the OECD does not collect data on the educational characteristics of immigrants. For example, since the educational distribution of Turkish migrants to the OECD must be estimated on the basis of U.S. data, and the educational distribution of these OECD migrants might be quite different from that of their United States-bound compatriots, the figures in Table 7 might over-estimate the extent of the brain drain. Second, as in the United States, published data on the number of immigrants to the OECD exclude the large (and unknown) number of illegal immigrants to these countries, who are likely to have lower levels of education. For instance, it is likely that a large number of illegal immigrants from North Africa to the OECD have low levels of education, simply because rates of educational attainment in these North African countries are low. ${ }^{15}$

Table 7 presents migration rates by educational category for each labor-exporting country. Focusing on the tertiary level of education, the available data suggest that migration to the OECD causes more of a brain drain than it does in the United States. For 5 of the 13 countries for which data exist, more than 10 percent of those with a tertiary education have migrated to the OECD. For these five countries, the rates of

\footnotetext{
${ }^{15}$ For example, in Morocco and Tunisia about 76 percent of the population over age 25 has a primary school education or less.
} 
migration for those with a tertiary education range from 16.5 percent (Sri Lanka) to 95.8 percent (Jamaica). The latter country - Jamaica - must be suffering from a particularly high degree of brain drain, because it has the highest migration rate for tertiary-educated people to both the OECD and the United States (see Table 5).

The data in Table 7 suggest that migration to the OECD differs from that to the United States in another important way. While migration to the United States tends to take a high percentage of tertiary-educated people from neighboring (Latin American) countries, in the OECD the link between migration, education and geography is not so obvious. While three of the countries (Morocco, Tunisia and Turkey) with the highest rates for tertiary-educated migration are located close to the OECD, two other prominent countries (Jamaica and Sri Lanka) are not. More work needs to be done to identify the reasons why Jamaica and Sri Lanka send such a high proportion of their "best and brightest" to the OECD.

The final point to be noted in Table 7 is that total migration rates to the OECD are lower than those to the United States. While four labor-exporting countries have total migration rates in excess of 10 percent to the United States, no country in the OECD has a total migration rate above that mark. Jamaica has the highest overall migration rate to the $\mathrm{OECD}$, at 8.7 percent. Again, the combination of small population and a high degree of migration abroad lead Jamaica to record a higher migration rate than such large, laborexporting countries, like Turkey and the Philippines. 


\section{Conclusion}

While the level of international migration and remittances continues to grow between countries, data on the whole process of international migration remains fragmented, scattered and unreliable. At the international level, there is no consistent set of statistics on either the number or skill characteristics of international migrants. At the national level, labor-exporting countries do not typically keep track either of the number or the skill characteristics of migrants. And while some labor-receiving countries do keep track these issues, they often miss the large numbers of migrants who enter their borders on an illegal basis.

Using a new data set of 24 large, labor-exporting countries, and employing estimates of migration and educational attainment based on United States and OECD records, this paper has tried to overcome these data problems to answer such policy questions as: How pervasive is the brain drain from labor-exporting countries? Which countries or regions of the developing world are most affected? Does international migration deprive labor-exporting countries of a sizeable fraction of their "best and brightest," or are their numbers too small to worry about?

Five conclusions to these, and similar questions, emerge from this paper. While these conclusions are often based on estimates of migration which are rough and in need of further refinement, they are still suggestive.

The first finding is that the level of international migration continues to grow annually. While no accurate, time-series data exist on changes in the total level of international migration, the International Monetary Fund (IMF) does keep annual records on the level of official remittances sent home by migrant workers. Over the last twenty 
years, these records show that the official worker remittances have increased at a steady 3.86 percent per year for the 24 study countries. ${ }^{16}$ This annual rate of increase for official worker remittances is higher than that recorded for the annual rate of GDP growth (1.61 percent per year) in 119 low and lower middle-income developing countries over the last twenty years.

The second finding from this study is that with respect to legal migration, international migration definitely involves the movement of the educated. In both the United States and the OECD, individuals with a primary education account for less than 30 percent of total immigrants. The vast majority of immigrants to both regions (67 percent in the United States and 88 percent in the OECD) have a secondary (high school) education or higher. ${ }^{17}$ From an educational standpoint, international migrants represent an elite that is much better educated than the rest of the population in their country of origin.

The third finding is that while migrants are well-educated, international migration does not tend to take a very high proportion of the best educated (tertiary) population in labor-exporting countries. For 22 of the 33 countries in which educational attainment data can be estimated, ${ }^{18}$ less than 10 percent of the tertiary-educated population of laborexporting countries has migrated to the United States or the OECD. Part of the reason for this finding is that large labor-exporting countries are also typically large population

\footnotetext{
${ }^{16}$ If the figures for remittance flows which occur outside of official banking channels could be included, it is likely that total remittances - official and unofficial - would have increased at an even faster rate over the last twenty years.

${ }^{17}$ As emphasized in the paper, these figures do not include the large numbers of illegal (and presumably less educated) immigrants to the United States or the OECD.

${ }^{18}$ Table 5 presents 20 countries with educational attainment data, and Table 7 presents 13 countries.
} 
countries, which have a substantial number of tertiary-educated people. For example, one of the largest labor-exporters in this study - China, PR - has such a large pool of tertiary-educated people that international migration has a relatively small proportional impact on the domestic labor-market for the "best and brightest". 19

The fourth result follows from the preceding. For a handful of labor-exporting countries, international migration does cause brain drain. For example, for the five Latin American countries (Dominican Republic, El Salvador, Guatemala, Jamaica and Mexico) located closest to the United States, migration takes a large share of the best educated. Sixteen percent of those with a tertiary education in Mexico migrate to the United States, and over 360 percent of those with this level of education in Jamaica migrate. With respect to the OECD, international migration takes more than 10 percent of those with a tertiary education from five countries: Jamaica, Morocco, Tunisia, Turkey and Sri Lanka. Three of these large brain drain countries are located close to the OECD, while two of them (Jamaica and Sri Lanka) are not.

The final finding concerns promising directions for future work on the issue of brain drain. Results from this paper suggest that there is a close relationship between brain drain, geographical proximity to labor-receiving countries, and the size of the population (especially the educated population) of labor-exporting countries. In many cases lightly-populated countries located close to either the United States or the OECD suffer the highest rates of brain drain for tertiary-educated people. Good examples of this phenomenon include Jamaica, El Salvador and Tunisia, each of which have populations of less than ten million. More work needs to be done to clarify the relationship between

\footnotetext{
${ }^{19}$ For example, China, PR has an estimated number of $20,562,000$ people who have completed a tertiary education. Of this pool of highly-educated people, about 2.2 percent are immigrants in the United States and about 1.4 percent are immigrants in the OECD.
} 
brain drain, geography and population, and to identify possible policy programs for ameliorating the possibly adverse impact of brain drain on these countries. 


\section{$\underline{\text { References }}$}

Barro, Robert and Lee, Jong-Wha. 2000. Data Set on Educational Attainment of the Total Population Aged 25 and Over. Available on the web site of the Center for International Development at Harvard University (www.ksg.harvard.edu/CID).

Borjas, George. 1995. “The Economic Benefits from Immigration,” Journal of Economic Perspectives, No. 9, pp. 3-22.

Carrington, William and Detragiache, Enrica. 1998. "How Big is the Brain Drain?," MF Working Paper WP/98/102, International Monetary Fund, Washington, DC, July 1998.

International Monetary Fund (IMF). (Various). Balance of Payments Statistics Yearbook. Washington, DC.

Organization for Economic Cooperation and Development (OECD). 2001. Trends in International Migration: Annual Report. Paris, France.

El-Qorchi, Mohammed, Maimbo, Samuel and Wilson, John. 2002. "The Hawala Informal Funds Transfer System: An Economic and Regulatory Analysis." Unpublished paper, August 2002.

United States, Census Bureau. 2000. Population Census. Washington, DC.

United States, Census Bureau. 2003. Special Tabulation on Educational Attainment of

Foreign-Born Population in the U.S. Based on 2000 Population Census. Washington, DC.

World Bank. 2000. World Development Report, 2000/01. Washington, DC. 
Table 1. Official Worker Remittances Received in 24 Selected Labor-Exporting Countries, 1981 - 2000 (in millions of US Dollars; Real Terms)

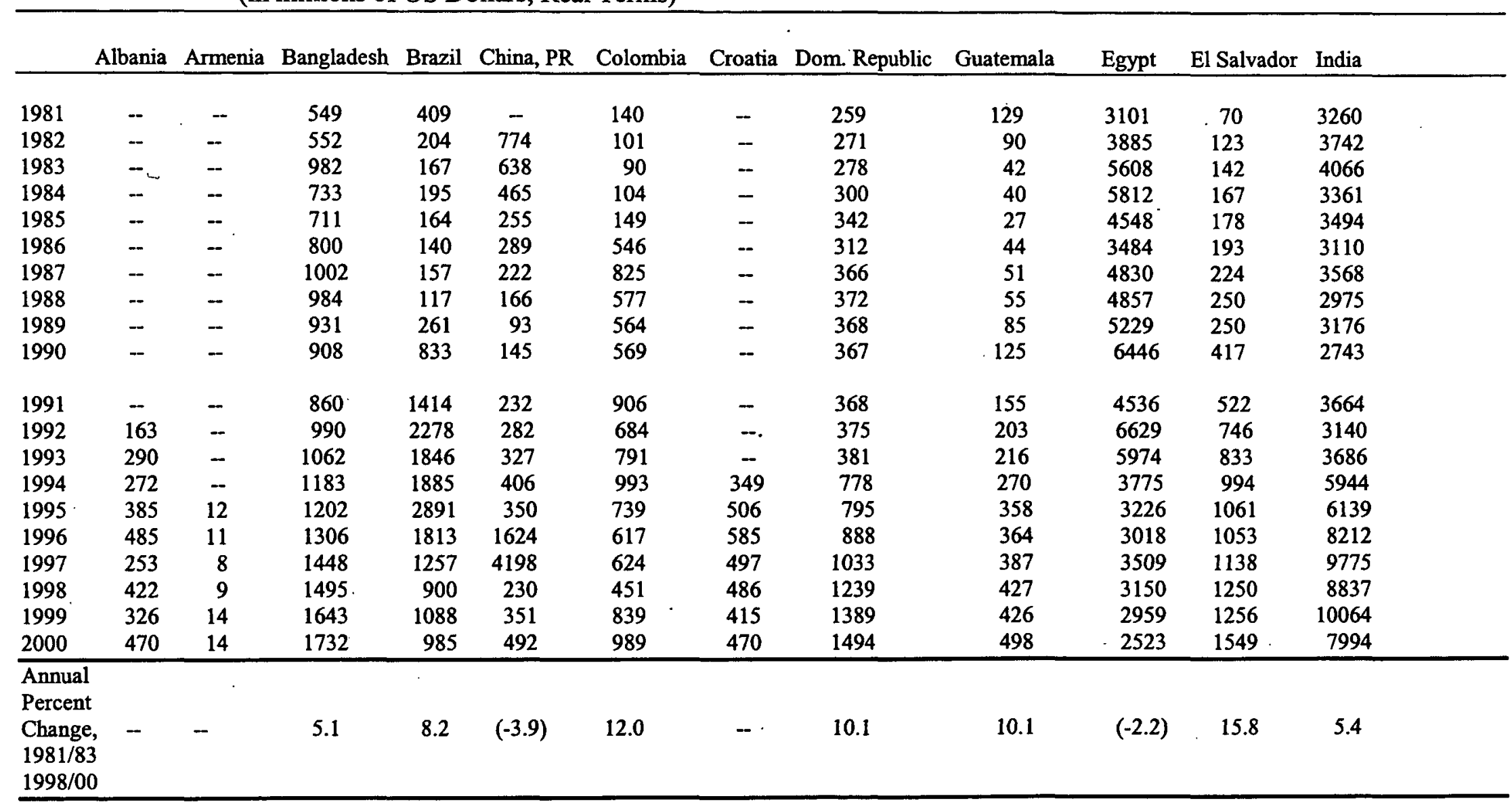

-- Table continued on next page -- 
Table 1 (contd) Official Worker Remittances Received in 24 Selected Labor-Exporting Countries, 1981 - 2000

(in millions of US Dollars; Real Terms)

Indonesia Jamaica Mexico Morocco Nigeria Pakistan Peru Philippines Sri Lanka Sudan Tunisia Turkey

\begin{tabular}{|c|c|c|c|c|c|c|c|c|c|c|c|c|}
\hline 1981 & - & 89 & 183 & 1440 & 11 & 2923 & 231 & 360 & 469 & - & 507 & 3540 \\
\hline 1982 & - & 106 & 155 & 1214 & 19 & 3690 & 240 & 342 & 456 & 208 & 532 & 3060 \\
\hline 1983 & 15 & 59 & 169 & 1311 & 12 & 4476 & 315 & 257 & 449 & 420 & 514 & 2165 \\
\hline 1984 & 78 & 38 & 259 & 1278 & 10 & 3768 & 231 & 86 & 441 & 418 & 465 & 2650 \\
\hline 1985 & 86 & 130 & 245 & 1369 & 14 & .3575 & 189 & 157 & 415 & 369 & 383 & 2427 \\
\hline 1986 & 98 & 75 & 250 & 1943 & 7 & 3385 & 208 & 226 & 453 & 157 & 502 & 2271 \\
\hline 1987 & 115 & 79 & 277 & 2127 & 4 & 2908 & 241 & 282 & 469 & 185 & 651 & 2708 \\
\hline 1988 & 127 & 87 & 269 & 1678 & 3 & 2400 & 203 & 500 & 461 & 279 & 701 & 2288 \\
\hline 1989 & 205 & 144 & 2180 & 1642 & 12 & 2468 & 290 & 442 & 440 & 512 & 600 & 3726 \\
\hline 1990 & 194 & 159 & 2906 & 2339 & 12 & 2329 & 288 & 305 & 467 & 72 & 642 & 3785 \\
\hline 1991 & 145 & 152 & 2701 & 2226 & 74 & 1724 & 353 & 368 & 494 & 50 & 587 & 3154 \\
\hline 1992 & 248 & 171 & 3334 & 2356 & 61 & 1700 & 267 & 342 & 595 & 135 & 576 & 3266 \\
\hline 1993 & 365 & 197 & 3514 & 2006 & 836 & 1518 & 332 & 328 & 666 & 79 & 470 & 3079 \\
\hline 1994 & 461 & 470 & 3572 & 1878 & 565 & 1798 & 485 & 455 & 735 & 110 & 646 & 2700 \\
\hline 1995 & 651 & 582 & 3673 & 1970 & 804 & 1712 & 600 & 432 & 790 & 346 & 680 & 3327 \\
\hline 1996 & 773 & 618 & 4103 & 2103 & 920 & 1247 & 579 & 552 & 808 & 214 & 715 & 3441 \\
\hline 1997 & 688 & 609 & 4618 & 1797 & 1822 & 1620 & 603 & 1003 & 875 & 394 & 650 & 3984 \\
\hline 1998 & 896 & 618 & 5260 & 1879 & 1471 & 1095 & 605 & 190 & 936 & 642 & 671 & 5007 \\
\hline 1999 & 1014 & 627 & 5405 & 1772 & 1198 & 911 & 614 & 93 & 962 & 607 & 696 & 4143 \\
\hline 2000 & 1053 & 698 & 5816 & 1912 & - & 951 & 635 & 111 & 1010 & 564 & 619 & 4035 \\
\hline $\begin{array}{l}\text { Annual } \\
\text { Percent } \\
\text { Change, } \\
1981 / 83 \\
1998 / 00\end{array}$ & 27.9 & 12.7 & 22.7 & 2.0 & 30.7 & -7.5 & 5.2 & $(-130.0)$ & 4.5 & 3.9 & 1.5 & 2.4 \\
\hline
\end{tabular}

Note: Real figures calculated by deflating nominal figures by US Consumer Price Index $(1995=100)$. Data record only those worker remittances which enter the official banking system.

Sources: International Monetary Fund, Balance of Payments Statistics Yearbook (various issues). 
Table 2. Official Worker Remittances Received in 24 Selected Labor-Exporting Countries, Classified by Region of the World, 1981 2000 (in millions of US Dollars; Real Terms)

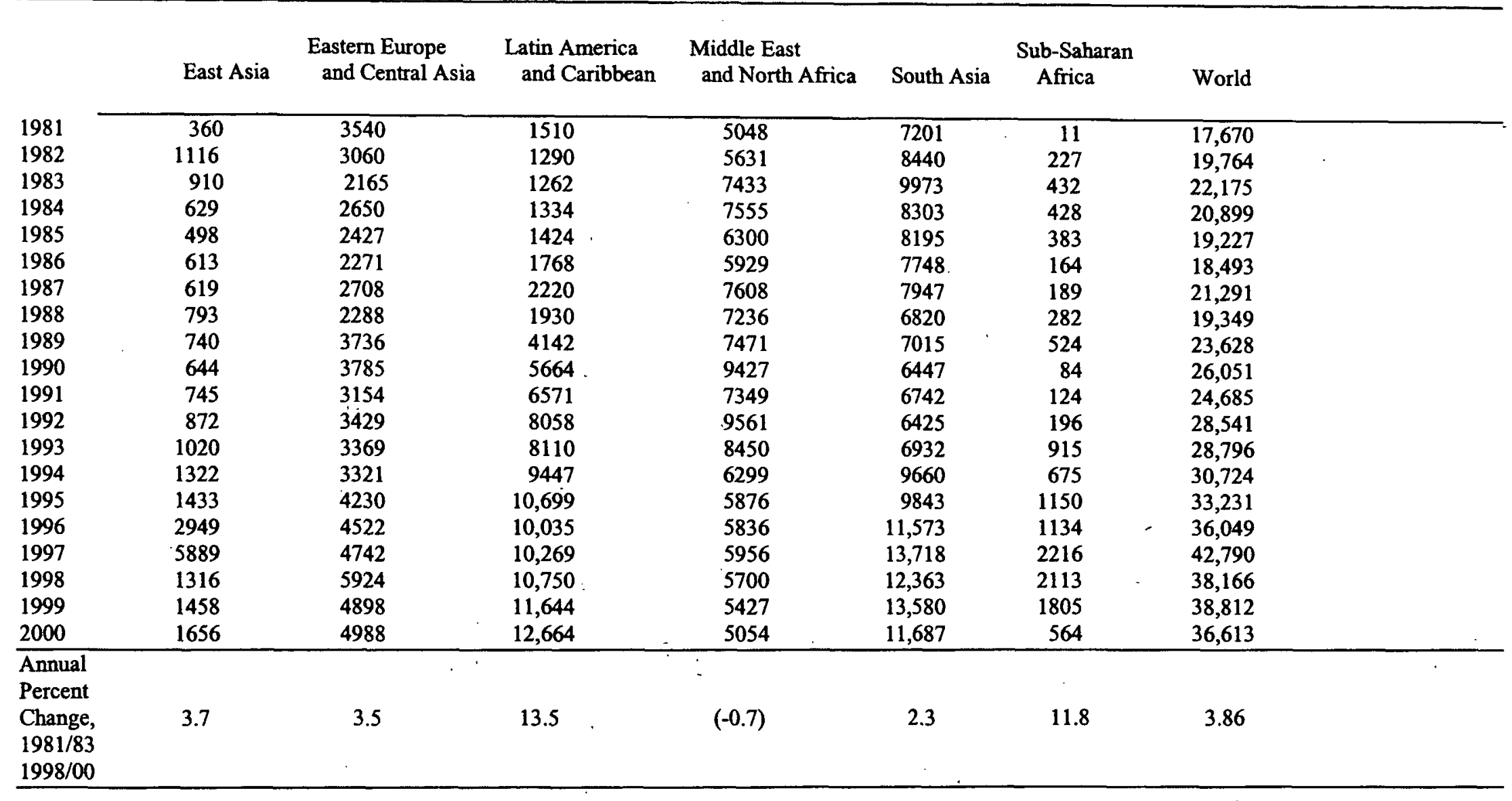

Note: Real figures calculated by deflating nominal figures by US Consumer Price Index $(1995=100)$. Data record only those worker remittances which enter the official banking system. The 24 countries included in the table are listed in Table 1.

Sources: International Monetary.Fund, Balance of Payments Statistics Yearbook (various issues). 
Table 3. Comparing Annual Rates of Growth of Official Worker Remittances and Gross Domestic Product (GDP) by Region of the World, $1981 / 83$ to $1998 / 00$

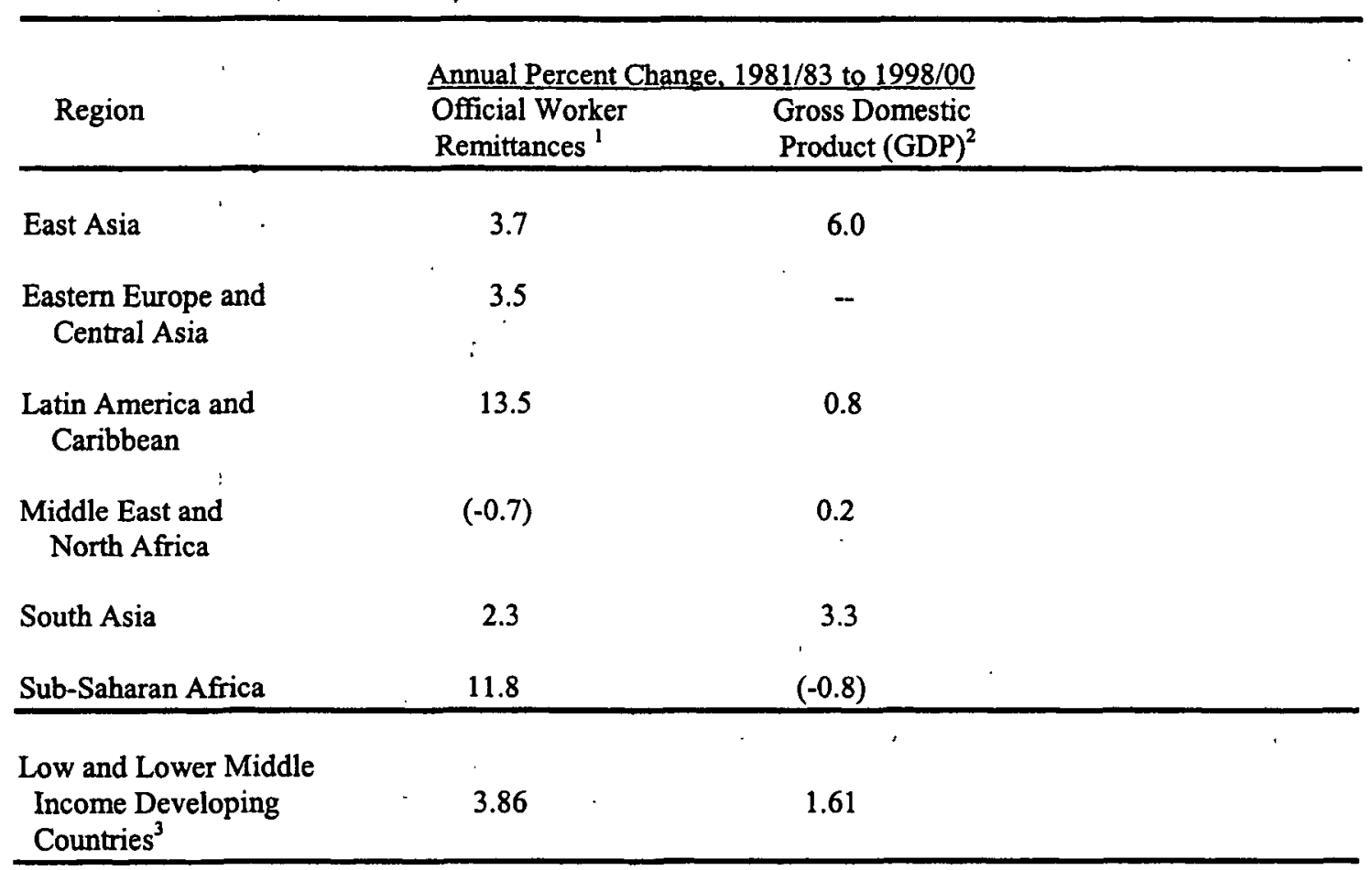

Notes:

'Official worker remittances are measured in real terms by deflating nominal figures by US Consumer Price Index $(1995=100)$. Official worker remittances include remittances received by the 24 study countries, and include only remittances which enter the official banking system. The 24 study countries are listed in Table 1.

${ }^{2}$ Gross domestic product is measured on a per capita basis using constant 1995 US dollars. No GDP data are available for Eastern Europe and Central Asia in 1981/83.

${ }^{3}$ For official worker remittances, the category "low and lower middle-income developing countries" includes the 24 study countries; for gross domestic product, the category "low and lower middle-income developing countries" includes 119 countries, which are classified by the World Bank (2000) as falling into this category.

Sources: issues).

Remittance data: International Monetary Fund, Balance of Payments Statistics Yearbook (various

GDP data: World Bank, World Development Indicators database (2002). 
Table 4. Number of Immigrants (Age 25 and older) to the United States by Level of Educational Attainment, 2000

\begin{tabular}{|c|c|c|c|c|}
\hline \multirow[b]{2}{*}{ Country } & \multirow{2}{*}{$\begin{array}{l}\text { Total } \\
\text { Immigrants }\end{array}$} & \multicolumn{3}{|c|}{ Educational Level } \\
\hline & & Primary or less & Secondary & Tertiary \\
\hline \multicolumn{5}{|l|}{ East Asia } \\
\hline China, PR & 846,780 & 173,545 & 217,185 & 456,050 \\
\hline Indonesia & 53,170 & 1,460 & 12,065 & 39,645 \\
\hline Philippines & $1,163,555$ & 90,200 & 228,955 & 844,400 \\
\hline \multicolumn{5}{|l|}{$\begin{array}{l}\text { Eastern Europe, } \\
\text { Central Asia }\end{array}$} \\
\hline Albania & 25,785 & 3,540 & 12,400 & 9,845 \\
\hline Armenia & 44,380 & 3,815 & 17,975 & 22,590 \\
\hline Croatia & 35,455 & 6,725 & 14,350 & 14,380 \\
\hline Turkey & 64,780 & 8,905 & 18,090 & 37,785 \\
\hline \multirow{2}{*}{\multicolumn{5}{|c|}{$\begin{array}{l}\text { Latin America, } \\
\text { Caribbean }\end{array}$}} \\
\hline & & & & \\
\hline Brazil & 154,250 & 14,005 & 56,010 & 84,235 \\
\hline Colombia & 402,935 & 53,485 & 163,415 & 186,035 \\
\hline Dom. Republic & 527,520 & 155,685 & 226,270 & 145,565 \\
\hline El Salvador & 619,185 & 255,170 & 257,455 & 106,560 \\
\hline Guatemala & 341,590 & 146,515 & 127,860 & 67,215 \\
\hline Jamaica & 449,795 & 36,430 . & 209,710 & 203,655 \\
\hline Mexico & $6,374,825$ & $3,081,310$ & $2,398,000$ & 895,515 \\
\hline Peru & 220,815 & 16,965 & 87,085 & 116,765 \\
\hline \multicolumn{5}{|l|}{$\begin{array}{l}\text { Middle East, } \\
\text { North Africa }\end{array}$} \\
\hline Egypt & 96,660 & 3,480 & 18,010 & 75,170 \\
\hline Morocco & 29,670 & 1,625 & 8,900 & 19,145 \\
\hline Tunisia & 5,555 & 390 & 1,625 & 3,540 \\
\hline \multicolumn{5}{|l|}{ South Asia } \\
\hline Bangladesh & 69,180 & 6,000 & 20,095 & 43,085 \\
\hline India & 836,780 & 41,185 & 127,540 & 668,055 \\
\hline Pakistan & 165,425 & 11,630 & 43,365 & 110,430 \\
\hline Sri Lanka & 21,820 & 495 & 5,695 & 15,630 \\
\hline \multicolumn{5}{|l|}{$\begin{array}{l}\text { Sub-Saharan } \\
\text { Africa }\end{array}$} \\
\hline Nigeria & 109,160 & 2,630 & 15,910 & 90,620 \\
\hline Sudan & 12,730 & 960 & 3,715 & 8,055 \\
\hline Total & $2,671,800$ & $4,116,150$ & $4,291,680$ & $4,263,970$ \\
\hline
\end{tabular}

Notes: Immigrants defined as foreign born population in the United States age 25 years or over. Primary education or less corresponds to $0-8$ years of schooling; secondary to 9-12 years of schooling, and tertiary to more than 12 years of schooling

Source: Special tabulation from U.S. Census Bureau based on 2000 U.S. Population Census. 
Table 5. Migration Rates to the United States by Level of Educational Attainment, 2000

\begin{tabular}{|c|c|c|c|c|}
\hline \multirow[b]{2}{*}{ Country } & \multirow[b]{2}{*}{ Total } & \multicolumn{2}{|c|}{ Educational Level } & \multirow[b]{2}{*}{ Tertiary } \\
\hline & & Primary or less & Secondary & \\
\hline \multicolumn{5}{|l|}{ East Asia } \\
\hline China, PR & 0.1 & 0.1 & 0.2 & 2.2 \\
\hline Indonesia & 0.1 & 0.1 & 0.1 & 0.7 \\
\hline Philippines & 3.6 & 0.6 & 2.2 & 11.7 \\
\hline \multirow{2}{*}{\multicolumn{5}{|c|}{$\begin{array}{l}\text { Eastern Europe, } \\
\text { Central Asia }\end{array}$}} \\
\hline & & & & \\
\hline Croatia & 1.2 & 0.4 & 1.2 & 4.7 \\
\hline Turkey & 0.2 & 0.1 & 0.4 & 1.3 \\
\hline \multicolumn{5}{|l|}{$\begin{array}{l}\text { Latin America, } \\
\text { Caribbean }\end{array}$} \\
\hline$\overline{\text { Brazil }}$ & 0.2 & 0.1 & 0.5 & 1.1 \\
\hline Colombia & 2.1 & 0.4 & 4.0 & 9.9 \\
\hline Dom. Republic & 12.9 & 5.3 & 42.4 & 24.8 \\
\hline El Salvador & 24.3 & 12.4 & 114.8 & 39.5 \\
\hline Guatemala & 7.6 & 3.8 & 29.9 & 25.8 \\
\hline Jamaica & 33.3 & 4.7 & 40.9 & 367.6 \\
\hline Mexico & 13.3 & 10.8 & 17.2 & 16.5 \\
\hline Peru & 1.8 & 0.3 & 2.5 & 4.2 \\
\hline \multirow{2}{*}{\multicolumn{5}{|c|}{$\begin{array}{l}\text { Middle East, } \\
\text { North Africa }\end{array}$}} \\
\hline & & & & \\
\hline Egypt & 0.3 & 0.1 & 0.2 & 2.3 \\
\hline Tunisia & 0.1 & 0.1 & 0.2 & 1.3 \\
\hline \multicolumn{5}{|l|}{ South Asia } \\
\hline Bangladesh & 0.1 & 0.1 & 0.3 & 2.3 \\
\hline India & 0.2 & 0.1 & 0.2 & 2.8 \\
\hline Pakistan & 0.3 & 0.1 & 0.5 & 6.4 \\
\hline Sri Lanka & 0.2 & 0.1 & 0.1 & 5.6 \\
\hline \multicolumn{5}{|l|}{ Sub-Saharan } \\
\hline \multicolumn{5}{|l|}{ Africa } \\
\hline Sudan & 0.1 & 0.1 & 0.3 & 3.4 \\
\hline
\end{tabular}

Notes: No educational attainment data available on: Albania, Armenia, Morocco and Nigeria. Immigrants defined as foreign born population in the United States, age 25 years or over. Primary education or less corresponds to 0-8 years of schooling; secondary to 9-12 years of schooling, and tertiary to more than 12 years of schooling.

Source: Author's calculations using data from special tabulation from U.S. Census Bureau based on 2000 U.S. Population Census, and the Barro-Lee data set (2000) on educational attainment. 
Table 6. Number of Immigrants (Age 25 and older) to the OECD by Level of Educational Attainment, 2000

\begin{tabular}{|c|c|c|c|c|}
\hline \multirow[b]{2}{*}{ Country } & \multirow{2}{*}{$\begin{array}{l}\text { Total } \\
\text { Immigrants }\end{array}$} & \multicolumn{2}{|c|}{ Educational Level } & \multirow[b]{2}{*}{ Tertiary } \\
\hline & & Primary or less & Secondary & \\
\hline \multicolumn{5}{|l|}{ East Asia } \\
\hline China, PR & 722,400 & 148,029 & 185,295 & 389,076 \\
\hline Indonesia & 142,540 & 3,910 & 32,347 & 106,283 \\
\hline Philippines & 356,134 & 27,604 & 70,079 & 258,451 \\
\hline \multicolumn{5}{|c|}{$\begin{array}{l}\text { Eastern Europe, } \\
\text { Central Asia }\end{array}$} \\
\hline Turkey & $1,913,782$ & 263,078 & 534,429 & $1,116,275$ \\
\hline $\begin{array}{l}\text { Latin America, } \\
\text { Caribbean }\end{array}$ & & & & - \\
\hline Brazil & 176,519 & 16,026 & 64,097 & 96,396 \\
\hline Jamaica & 117,199 & 9,483 & 54,647 & 53,069 \\
\hline \multicolumn{5}{|l|}{$\begin{array}{l}\text { Middle East, } \\
\text { North Africa }\end{array}$} \\
\hline Morocco & 560,658 & 30,706 & 168,179 & 361,773 \\
\hline Tunisia & 142,828 & 10,027 & 41,782 & 91,019 \\
\hline Egypt & 20,373 & 733 & 3,796 & 15,844 \\
\hline \multicolumn{5}{|l|}{ South Asia } \\
\hline Bangladesh & 44,417 & 3,852 & 12,902 & 27,663 \\
\hline India & 375,283 & 18,471 & 57,199 & 299,613 \\
\hline Pakistan & 85,668 & 6,022 & 22,458 & 57,188 \\
\hline Sri Lanka & 64,143 & 1,455 & 16,741 & 45,947 \\
\hline Total & $4,721,944$ & 539,396 & $1,263,951$ & $2,918,597$ \\
\hline
\end{tabular}

Notes: No data available on number of immigrants from: Albania, Armenia, Colombia, Croatia, Dom. Republic, El Salvador, Guatemala, Mexico, Nigeria, Peru and Sudan. Immigrants defined as immigrant or foreign born population by individual countries in the OECD, age 25 years or over. Primary education or less corresponds to 0-8 years of schooling; secondary to 9-12 years of schooling, and tertiary to more than 12 years of schooling. For a list of OECD countries, see footnote (4).

Source: Author's calculations from OECD, Trends in International Migration: Annual Report (2001). 
Table 7. Migration Rates to the OECD by Level of Educational Attainment, 2000

\begin{tabular}{|c|c|c|c|c|}
\hline \multirow[b]{2}{*}{ Country } & \multicolumn{4}{|c|}{ Educational Level } \\
\hline & Total & Primary or less & Secondary & Tertiary \\
\hline \multicolumn{5}{|l|}{ East Asia } \\
\hline China, PR & 0.1 & 0.1 & 0.1 & 1.9 \\
\hline Indonesia & 0.1 & 0.1 & 0.2 & 2.0 \\
\hline Philippines & 1.1 & 0.2 & 0.7 & 3.6 \\
\hline \multicolumn{5}{|c|}{$\begin{array}{l}\text { Eastern Europe, } \\
\text { Central Asia }\end{array}$} \\
\hline Turkey & 5.7 & 1.0 & 11.5 & 39.1 \\
\hline \multicolumn{5}{|l|}{$\begin{array}{l}\text { Latin America, } \\
\text { Caribbean }\end{array}$} \\
\hline Brazil & 0.2 & 0.1 & 0.6 & 1.3 \\
\hline Jamaica & 8.7 & 1.2 & 10.6 & 95.8 \\
\hline \multicolumn{5}{|l|}{$\begin{array}{l}\text { Middle East, } \\
\text { North Africa }\end{array}$} \\
\hline Morocco & 4.0 & 0.3 & 6.9 & 43.5 \\
\hline Tunisia & 3.1 & 0.3 & 5.2 & 33.3 \\
\hline Egypt & 0.1 & 0.1 & 0.1 & 0.5 \\
\hline \multicolumn{5}{|l|}{ South Asia } \\
\hline Bangladesh & 0.1 & 0.1 & 0.2 & 1.5 \\
\hline India & 0.1 & 0.1 & 0.1 & 1.3 \\
\hline Pakistan & 0.1 & 0.1 & 0.3 & 3.3 \\
\hline Sri Lanka & 0.7 & 0.1 & 0.4 & 16.5 \\
\hline
\end{tabular}

Notes: Immigrants defined as immigrant or foreign born population by individual countries in the OECD, age 25 years or over. Primary education or less corresponds to $0-8$ years of schooling ; secondary to 9-12 years of schooling, and tertiary to more than 12 years of schooling. For a list of OECD countries, see footnote (4).

Source: Author's calculations from OECD, Trends in International Migration: Annual Report (2001), and the Barro-Lee data set (2000) on educational attainment. 



\section{Policy Research Working Paper Series}

Title

WPS3043 The Incentive-Compatible Design of Deposit Insurance and Bank Failure Resolution: Concepts and Country Studies

WPS3044 Impregnated Nets Cannot Fully Substitute for DDT: Field Effectiveness of Malaria Prevention in Solomon Islands

WPS3045 Causes and Consequences of Civil Strife: Micro-Level Evidence from Uganda

WPS3046 Migration, Spillovers, and Trade Diversion: The Impact of Internationalization on Stock Market Liquidity

WPS3047 Comparing Mortgage Credit Risk Policies: An Options-Based Approach

Robert Buckley

Mead over

Bernard Bakote'e

Raman Velayudhan

Peter Wilikai

Patricia M. Graves

Klaus Deininger

Ross Levine

Sergio L. Schmukler

May 2003

Khine

37471

May 2003

O. Himid

80225

Robert Van Order

Laura Vecvagare

WPS3048 Targeted Transfers in Poor Countries: Martin Ravallion Revisiting the Tradeoffs and Policy Options

WPS3049 Hidden Impact? Ex-Post Evaluation of an Anti-Poverty Program

WPS3050 The Changing Financial Landscape: Opportunities and Challenges for the Middle East and North Africa

WPS3051 Regional, Multilateral, and Unilateral Trade Policies of MERCOSUR for Growth and Poverty Reduction in Brazil

WPS3052 Long-Run Impacts of China's WTO Accession on Farm-Nonfarm Income Inequality and Rural Poverty

WPS3053 Economic Impacts of China's Accession to the World Trade Organization

WPS3054 The New Comparative Economics

WPS3055 The Global Growth of Mutual Funds
Shaohua Chen

Martin Ravallion

Wafik Grais

Zeynep Kantur

Glenn W. Harrison

Thomas F. Rutherford

David G. Tarr

Angelo Gurgel

Kym Anderson

Jikun Huang

Elena lanchovichina

Elena lanchovichina

William Martin

May 2003

P. Sader

33902

May 2003

Simeon Djankov

Edward Glaeser

Rafael La Porta

Florencio Lopez-de-Silanes

Andrei Shleifer

Deepthi Fernando

Leora Klapper

Víktor Sulla

Dimitri Vittas
May 2003

May 2003

P. Flewitt

32724

May 2003

May 2003

S. Lipscomb 87266

May 2003

P. Sader 33902

R. Vo

33722

S. Lipscomb 87266

May 2003

G. Sorensen 37088

A. Yaptenco 31823 


\section{Policy Research Working Paper Series}

Title

WPS3056 Avoiding the Pitfalls in Taxing Financial Intermediation

WPS3057 Teaching Adults to Read Better and Faster: Results from an Experiment in Burkina Faso

WPS3058 Working for God? Evaluating Service Delivery of Religious Not-for-Profit Health Care Providers in Uganda

WPS3059 Do Capital Flows Respond to Risk and Return?

WPS3060 World Market Integration through the Lens of Foreign Direct Investors

\section{WPS3061 Reciprocity in Free Trade} Agreements

WPS3062 Labor Effects of Adult Mortality in Tanzanian Households

WPS3063 Trade Liberalization, Firm Performance, and Labor Market Outcomes in the Developing World: What Can We Learn from Micro-Level Data?

WPS3064 Trade Policy, Trade Volumes, and Plant-Level Productivity in Colombian Manufacturing Industries

WPS3065 Ghost Doctors: Absenteeism in Bangladeshi Health Facilities

WPS3066 The Potential Demand for and Strategic Use of an HIV-1 Vaccine in Southern India

Ana M. Fernandes

César Calderón

WPS3067 The Mini-Integrated Macroeconomic Pierre-Richard Agénor Model for Poverty Analysis: A Framework for Analyzing the Unemployment and Poverty Effects of Fiscal and Labor Market Reforms

WPS3068 Poverty and Economic Growth in Egypt, 1995-2000 Norman Loayza Luis Servén

Rui Altuquerque Norman Loayza Luis Servén

Caroline Freund

Kathleen Beegle

Paolo Epifani

Nazmul Chaudhury Jeffrey S. Hammer

Shreelata Rao Seshadri

P. Subramaniyam

Prabhat Jha

Heba El-laithy Michael Lokshin Arup Banerji

\section{Date}

May 2003

May 2003

May 2003

May 2003

May 2003

May 2003

May 2003

May 2003

May 2003

May 2003

May 2003

May 2003

Contact for paper

A. Yaptenco 31823

H. Abadzi 80375

H. Sladovich 37698

T. Tourougui 87431

T. Tourougui 87431

P. Flewitt 32724

E. de Castro 89121

P. Flewitt 32724

A. Fernandes 33983

H. Sladovich 37698

H. Sladovich 37698

M. Gosiengfiao 33363

June 2003

P. Sader 33902 